ISSN: 2224-0616

Int. J . Agril. Res. Innov. \& Tech. 4 (2): 55-60, December, 2014 Available online at http:// www.ijarit.webs.com

\title{
IN VIVO EVALUATION OF WHEAT (Triticum aestivum L.) CULTIVARS FOR MOISTURE STRESS
}

\author{
S. Tamiru* and H. Ashagre \\ Received 25 August 2014, Revised 16 November 2014, Accepted 22 December 2014, Published online 31 December 2014
}

\begin{abstract}
In Ethiopia, wheat productivity is constrained by water stress especially at germination and seedling stage. The objective of this research was to determine the effect of moisture stress on bread wheat (Triticum aestivum) cultivars. Four wheat cultivars (Danda'a, Kubsa, Huluka and Local) were treated with six levels of water stress (0, 50, 100, 150, 200 and 250 $\mathrm{g} \mathrm{L}^{-1}$ ) using PEG-6000. The experiment was arranged factorally in completely randomized design with three replications. Data on germination and growth indices were collected and analyzed using one way ANOVA. The result revealed that highest germination percentage (99.7\%), germination rate (14.6 plants day ${ }^{-1}$ ) and seedling vigor index (9.67) were obtained from the local cultivar. Progressive increase in water stress had also significantly reduced germination indices. There was no significant difference among the cultivars in producing taller root and shoot length. The local cultivar had significantly produced highest root number $(4.3$ plant-1), shoot fresh weight $(0.214 \mathrm{~g})$, seedling fresh $(0.314 \mathrm{~g})$ and dry weight $(0.097 \mathrm{~g})$. Even though, all the growth parameters of wheat cultivars showed a diminishing trend with increasing the level of PEG-6000 induced water stress, a highly significant decrease in the parameters were observed starting from $150 \mathrm{~g} \mathrm{~L}^{-1} \mathrm{PEG}$ concentration. Higher shoot length inhibition was observed for Danda'a cultivar followed by Huluka. Huluka's root growth was more inhibited than Danda'a. According to the growth and germination indices results, the local cultivar is the drought tolerant wheat cultivar.
\end{abstract}

Keywords: Bread Wheat, Moisture Stress, Cultivars, PEG-6000

College of Agriculture and Veterinary Sciences, Department of Plant Sciences, Ambo University, Ambo, Ethiopia

*Corresponding author's email: solmill2000@gmail.com (S. Tamiru)

\section{Introduction}

Wheat (Triticum aestivum L.) is a staple food for more than $35 \%$ of the world population and is also the leading grain crops in most of the developing countries (Metwali et al., 2011). In Ethiopia, the total area devoted for wheat production was estimated to be 1.68 million ha with an average yield of $1827 \mathrm{~kg} \mathrm{ha}^{-1}$ (CSA, 2011). Wheat productivity in Ethiopia is influenced by biotic and abiotic factors. Moisture stress is among the major limiting abiotic factors hinder the productivity of Triticum aestivum. Abiotic stress, especially drought stress is a worldwide problem, seriously constraining global crop production (Pan et al., 2002). It is one of the major causes of crop loss worldwide, which commonly reduces average yield for many crop plants by more than $50 \%$ (Bayoumi et al., 2008). Plants may be affected by drought at any time of life, but certain stages such as germination and seedling growth are critical (Dhanda et al., 2004). One of the most important abiotic factors limiting plant germination and early seedling stages is water stress brought about by drought and salinity (Almansouri et al., 2001), which are widespread problems around the world (Soltani et al., 2006)
Germination and seedling growth stages are the most critical periods in the life cycle of plants. Under water stress, low water potential is a determining factor inhibiting seed germination (Xu et al., 2006). It is also important to determine the potential for seed germination in osmotic stress conditions, because, in this phase resistance against osmotic stress is a genetic quality and it is a good criterion for selection of stress resistant populations (Gharoobi et al., 2012). According to Boureima et al. (2011), good germination capacity and seedling growth in water deficit conditions are drought tolerance indices, which allow better prediction on the crop establishment. In addition, field experiments related to water stress has been difficult to handle due to significant environmental or drought interactions with other abiotic stresses (Rauf et al., 2008). An alternative approach is to induce water stress through polyethylene glycol 6000 (PEG 6000) solutions for screening of the germplasm (Khodarahmpour, 2011). Therefore, the objective of the current experiment was to determine moisture stress effect on bread wheat cultivars at germination and seedling growth stage. 


\section{Materials and Methods}

In vivo experiment was conducted in November 2013 at the Department of Plant Sciences, Ambo University, to investigate the effect of moisture stress on germination and seedling growth of wheat. The experiment was arranged factorially in completely randomized design with three replications. Four wheat cultivars (Danda'a, Kubsa, Hulluka, and Local) were treated with six levels of water stress $(0,50,100,150,200$ and $\left.250 \mathrm{~g} \mathrm{~L}^{-1} \mathrm{PEG}\right)$ for the experiment; de-ionized water was used for the control treatment. Polyethylene Glycol Solution (PEG-6000) used as a source of moisture stress was prepared by dissolving the respective treatment amount at 25 ${ }^{\circ} \mathrm{C}$ with deionized water. Seeds were surface sterilized with $0.01 \% \mathrm{HgCl}_{2}$ solution for $1 \mathrm{~min}$, and rinsed with deionized water.

Twenty seeds were uniformly placed on Watman filter paper covered the Petri dish $(9.5 \mathrm{~cm}$ diameter) using a forceps per treatment, and well soaked by adding $8 \mathrm{ml}$ with the respective solutions. All the Petri dishes were covered with lids and kept at room temperature $\left(22 \pm 2^{\circ} \mathrm{C}\right)$. Germination continued for 10 days, and germinated seeds were counted daily. Germination was considered to have occurred when radicles attained a length of $2 \mathrm{~mm}$. After 10 days, parameters such as per-cent germination and rate of germination were calculated according to ISTA (1999); and root and shoot lengths of seedling were measured using a scale. Root and shoot dry weights were recorded after oven drying for $72 \mathrm{~h}$ at $60^{\circ} \mathrm{C}$. The seedling vigor index (SVI) was determined as Hosseein and Kasra (2011). Statistical analysis of the data was performed using one-way ANOVA using SAS statistical software (Version 9). Based on the ANOVA results, mean separations were performed by LSD test at $5 \%$ level.

\section{Results and Discussion}

\section{Germination percentage}

Among all test varieties, the local variety produced the highest germination percentage (99.7\%). This indicates the superiority of the local variety over the improved varieties in terms of germination capacity under water stress condition (Table 1). Water stress level induced by $50 \mathrm{~g} \mathrm{~L}^{-1}$ PEG resulted the highest germination percentage (100\%) and it showed a decreasing trend with increase in PEG concentration where $250 \mathrm{~g} \mathrm{~L}^{-1}$ PEG produced the lowest percentage (92.5\%). Progressive increase in moisture stress had adversely affected germination capacity of wheat cultivars (Table 2). Similar results were found for linseed (Linum usitatissimum L) and cotton cultivars seeds as a consequence of increasing PEG concentration, because of diminished movement and accessibility of water for seed imbibitions (Guo et al., 2012; Meneses et al., 2011).

\section{Germination rate}

The highest numbers of seeds germinated were recorded for local variety with 14.6 plants day ${ }^{1}$, which showed its high genetic capacity for fast velocity of germination. Variety Kubsa showed the lowest number of seeds germinated thus slow velocity of germination followed by Danda'a (Table 1). Kubsa and Danda'a were highly susceptible to moisture stress induced by PEG as compared to the local cultivar. Regarding different PEG induced water stress, the highest numbers of seeds were germinated for non-stress (control) treatment with 17.5 plants day-1, and it followed diminishing trend when PEG concentration was increased from 50 to $250 \mathrm{~g} \mathrm{~L}^{-1}$ (Table 2). This delay in seed germination result obtained at more water stress levels were also found in cotton cultivars (Meneses et al., 2011).

\section{Seedlings vigor index}

The analysis result revealed that the seedling vigor index of the local variety was 23.2, 14.6 and $6 \%$ higher than the vigor index of Huluka, Danda'a and Kubsa cultivars, respectively (Table 1). The vigor index of wheat cultivar seeds produced by inducing water stress at 50 and 100 $\mathrm{g} \mathrm{L}^{-1} \mathrm{PEG}$ were not significantly different from non-stress ( $\left.0 \mathrm{~g} \mathrm{~L}^{-1} \mathrm{PEG}\right)$ treatment. Seedling vigor index showed significant difference and decrease starting from seeds treated with water stress at $150 \mathrm{~g} \mathrm{~L}^{-1}$ to $250 \mathrm{~g} \mathrm{~L}^{-1}$ PEG where the lowest vigor index (2.793) was produced at the maximum water stress level (Table 2). Cokkizgin (2013) observed that seedling vigor index of pea (Pisum sativum L.) was decreased with increasing PEG concentration. Moraes et al. (2005) observed that the bean (Phaseolus vulgaris L.) seeds also presented a progressive decrease of vigor when PEG-6000 concentrations increase. Decreasing seed vigor index of wheat at high moisture levels was probably due to decreasing trend in shoot and root lengths (Table 2).

\section{Shoot and root length}

Both shoot and root lengths were affected by moisture stress induced by PEG but there was no significant difference among the wheat cultivars in producing taller shoot and root under moisture stress. Increasing PEG concentration has significantly reduced root and shoot lengths except at control and $50 \mathrm{~g} \mathrm{~L}^{-1}$ PEG where maximum shoot and root length were obtained. The reductions in shoot lengths were more drastic than root growth for each increase in PEG concentration. Drought stress suppressed shoot growth more than root growth and in certain cases root growth increased (Bibi et al., 2010; Younis et al., 2000). 
Table 1.Mean comparison of wheat cultivars' response to PEG induced water stress

\begin{tabular}{lcccccc}
\hline Varieties & $\begin{array}{c}\text { Germination } \\
(\%)\end{array}$ & $\begin{array}{c}\text { Germination rate } \\
\left(\text { plants day }{ }^{-1}\right.\end{array}$ & $\begin{array}{c}\text { Seedling } \\
\text { vigor index }\end{array}$ & $\begin{array}{c}\text { Shoot length } \\
(\mathrm{cm})\end{array}$ & $\begin{array}{c}\text { Root length } \\
(\mathrm{cm})\end{array}$ & $\begin{array}{c}\text { Root } \\
\text { number }\end{array}$ \\
\hline Danda'a & $97.2^{\mathrm{a}}$ & $11.1(4.2)^{\mathrm{b}}$ & $8.26^{\mathrm{bc}}$ & $4.9(3.0)^{\mathrm{a}}$ & $9.3(3.9)^{\mathrm{a}}$ & $3.3(2.8)^{\mathrm{c}}$ \\
Kubsa & $98.6^{\mathrm{ab}}$ & $10.7(4.2)^{\mathrm{b}}$ & $9.09^{\mathrm{ab}}$ & $5.2(3.1)^{\mathrm{a}}$ & $9.2(3.9)^{\mathrm{a}}$ & $3.6(2.9)^{\mathrm{b}}$ \\
Hulluka & $97.2^{\mathrm{b}}$ & $12.6(4.5)^{\mathrm{ab}}$ & $7.43^{\mathrm{c}}$ & $5.7(3.1)^{\mathrm{a}}$ & $8.9(3.9)^{\mathrm{a}}$ & $3.6(2.9)^{\mathrm{b}}$ \\
Local & $99.7^{\mathrm{b}}$ & $14.6(4.8) \mathrm{a}$ & $9.67^{\mathrm{a}}$ & $5.6(3.2)^{\mathrm{a}}$ & $9.6(4.0)^{\mathrm{a}}$ & $4.3(3.0)^{\mathrm{a}}$ \\
\hline
\end{tabular}

Means with the sameletter are not significantly different; data in parenthesis are square root transformed

Table 2. Effect of PEG induced water stress on germination and growth indices of wheat

\begin{tabular}{lcccccc}
\hline PEG $\left(\mathrm{g} \mathrm{L}^{-1}\right)$ & $\begin{array}{c}\text { Germination } \\
(\%)\end{array}$ & $\begin{array}{c}\text { Germination rate } \\
(\text { plants day })\end{array}$ & $\begin{array}{c}\text { Seedling } \\
\text { vigor index }\end{array}$ & $\begin{array}{c}\text { Shoot length } \\
(\mathrm{cm})\end{array}$ & $\begin{array}{c}\text { Root length } \\
(\mathrm{cm})\end{array}$ & $\begin{array}{c}\text { Root } \\
\text { number }\end{array}$ \\
\hline 0.0 & $99.6^{\mathrm{a}}$ & $17.5(5.1)^{\mathrm{a}}$ & $11.389^{\mathrm{a}}$ & $10.4(4.2)^{\mathrm{a}}$ & $13.9(4.7)^{\mathrm{a}}$ & $4.9(3.2)^{\mathrm{a}}$ \\
50 & $100^{\mathrm{a}}$ & $16.7(5.0)^{\mathrm{ab}}$ & $11.359^{\mathrm{a}}$ & $9.5(4.1)^{\mathrm{a}}$ & $13.8(4.7)^{\mathrm{a}}$ & $4.8(3.2)^{\mathrm{a}}$ \\
100 & $99.6^{\mathrm{a}}$ & $14.1(4.7)^{\mathrm{b}}$ & $11.856^{\mathrm{a}}$ & $6.8(3.6)^{\mathrm{b}}$ & $11.4(4.3)^{\mathrm{b}}$ & $4.6(3.1)^{\mathrm{a}}$ \\
150 & $98.3^{\mathrm{a}}$ & $10.4(4.2)^{\mathrm{c}}$ & $8.703^{\mathrm{b}}$ & $3.3(2.8)^{\mathrm{c}}$ & $8.8(3.9)^{\mathrm{c}}$ & $3.5(2.9)^{\mathrm{b}}$ \\
200 & $99.2^{\mathrm{a}}$ & $9.1(4.1)^{\mathrm{c}}$ & $5.559^{\mathrm{c}}$ & $1.6(2.2)^{\mathrm{d}}$ & $5.8(3.4)^{\mathrm{d}}$ & $2.8(2.7)^{\mathrm{c}}$ \\
250 & $92.5^{\mathrm{b}}$ & $5.8(3.3)^{\mathrm{d}}$ & $2.793^{\mathrm{d}}$ & $0.6(1.7)^{\mathrm{e}}$ & $1.8(2.3)^{\mathrm{e}}$ & $1.6(2.3)^{\mathrm{d}}$ \\
\hline
\end{tabular}

Means with the sameletter are not significantly different; data in parenthesis are square root transformed

\section{Root number}

Result in table 3 showed that the local cultivar had produced the highest root numbers (4.3) per plant, which indicated its high capacity to tolerate water stress conditions. In contrast, lower root numbers were produced by cultivar Danda'a. There was no significant difference in root number between Kubsa and Huluka cultivars. The reduction in root number became very low when PEG concentration was increased from 0 to $100 \mathrm{~g} \mathrm{~L}^{-1}$. Wheat cultivars root numbers were reduced by 28.4, 43 and $67.4 \%$ when PEG concentration was increased from control (distilled water) to 150,200 and $250 \mathrm{~g} \mathrm{~L}^{-1}$, respectively. Root number become the parameter most affected by water stress i.e. under severe water stress, a preference should be given to wheat cultivars, which could produce more number of roots per plant.

\section{Shoot fresh and dry weight}

Shoot fresh and dry weight (Table 3) differed among the four wheat cultivars grown under water stress conditions. The local cultivar produced high shoot fresh weight, which was significantly different from the rest cultivars. Even though, the local cultivar produced high shoot fresh weight, its ability to convert into dry matter was lower than Huluka and Danda'a, which recorded low shoot fresh weight and relatively high dry weight. Regarding the water stress levels, shoot fresh and dry weight followed a decreasing trend when PEG was increased from 0 to $250 \mathrm{~g} \mathrm{~L}^{-1}$. Shoot fresh weight decreased significantly at $50 \mathrm{~g} \mathrm{~L}^{-1}$ and by half when PEG concentrations were increased from 150 to 200 and 200 to $250 \mathrm{~g} \mathrm{~L}^{-1}$. The reduction in dry weight followed the same trend as fresh weight from 150 to $250 \mathrm{~g} \mathrm{~L}^{-1}$ PEG concentration. But, the reduction followed slight decrease from 0 to $100 \mathrm{~g}$ $\mathrm{L}^{-1} \mathrm{PEG}$ concentration.

\section{Root fresh and dry weight}

Root fresh and dry weights were less influenced by osmotic concentration of PEG, but both parameters decreased with increase in PEG concentration. Significant difference in root fresh weight was observed between control $\left(0 \mathrm{~g} \mathrm{~L}^{-1}\right.$ $\mathrm{PEG}$ ) and water stress greater than $150 \mathrm{~g} \mathrm{~L}^{-1} \mathrm{PEG}$. Sharp decrease in root fresh weight was noted than root dry weight with increasing the severity of moisture stress to wheat cultivars, suggesting that root dry weight is less affected by increasing moisture stress than fresh weight.

Table 3. Mean comparison of wheat cultivars' growth response to PEG induced water stress

\begin{tabular}{|c|c|c|c|c|c|c|}
\hline Varieties & $\begin{array}{l}\text { Shoot fresh } \\
\text { weight (g) }\end{array}$ & $\begin{array}{l}\text { Shoot dry } \\
\text { weight (g) }\end{array}$ & $\begin{array}{l}\text { Root fresh } \\
\text { weight (g) }\end{array}$ & $\begin{array}{l}\text { Root dry } \\
\text { weight (g) }\end{array}$ & $\begin{array}{l}\text { Seedling fresh } \\
\text { weight (g) }\end{array}$ & $\begin{array}{r}\text { Seedl } \\
\text { weic }\end{array}$ \\
\hline Danc & $.144(1339)^{b}$ & $.0246(1149)^{\mathrm{c}}$ & $0.113(1319)^{\mathrm{ab}}$ & $0587(1.232)^{\mathrm{a}}$ & $0.257(1.470)^{\mathrm{bc}}$ & $0.083(1.276)^{b c}$ \\
\hline Kubsa & $0.163(1.370)^{b}$ & $0.0279(1.159)^{b c}$ & $0.123(1.339)^{\mathrm{a}}$ & $0.0635(1.246)^{\mathrm{a}}$ & $0.287(1.507)^{a b}$ & $0.092(1.293)^{\mathrm{ab}}$ \\
\hline Hullu & $0.145(1.342)^{b}$ & $0.0286(1.161)^{\mathrm{b}}$ & $0.085(1.280)^{\mathrm{c}}$ & $0.0466(1.209)^{b}$ & $0.230(1446)^{c}$ & $0.075(1.265)^{\mathrm{c}}$ \\
\hline ocal & $0.214(1.419)^{\mathrm{a}}$ & $0.0393(1.187)^{a}$ & $0.099(1.307)^{b c}$ & $0.0574(1.235)^{\mathrm{a}}$ & $0.314(1.526)^{a}$ & $0.097(1.303)^{\mathrm{a}}$ \\
\hline
\end{tabular}

Means with the sameletter are not significantly different; data in parenthesis are square root transformed 
Table 4. Effect of PEG induced water stress on growth indexes of wheat

\begin{tabular}{|c|c|c|c|c|c|c|}
\hline $\mathrm{G}\left(\mathrm{gL}^{-1}\right)$ & $\begin{array}{l}\text { Shoot fresh } \\
\text { weight (g) }\end{array}$ & $\begin{array}{l}\text { Shoot dry } \\
\text { weight }(\mathrm{g})\end{array}$ & $\begin{array}{l}\text { Root fresh } \\
\text { weight (g) }\end{array}$ & $\begin{array}{l}\text { Root dry } \\
\text { weight (g) }\end{array}$ & $\begin{array}{l}\text { Seedling fresh } \\
\text { weight (g) }\end{array}$ & $\begin{array}{l}\text { Seedlingdry } \\
\text { weight (g) }\end{array}$ \\
\hline 0.0 & $(1.55)^{a}$ & $0.047(1.22)^{\mathrm{a}}$ & $0.15(1.38)^{\mathrm{a}}$ & $\overline{067(1.26)^{\mathrm{ab}}}$ & 0.45 & 338) ${ }^{\mathrm{a}}$ \\
\hline 50 & $0.281(1.52)^{\mathrm{a}}$ & $0.043(1.21)^{\mathrm{ab}}$ & $0.14(1.37)^{\mathrm{a}}$ & $0.070(1.26)^{\mathrm{a}}$ & $0.414(1638)^{a b}$ & $0.114(1.336)^{\mathrm{a}}$ \\
\hline 100 & $0.222(1.47)^{b}$ & $0.042(1.20)^{\mathrm{b}}$ & $0.13(1.36)^{a}$ & $0.078(1.28)^{\mathrm{a}}$ & $0.361(1.597)^{b}$ & $0.119(1.344)^{\mathrm{a}}$ \\
\hline 150 & $0.125(1.34)^{\mathrm{c}}$ & 0.02 & $0.10(1.32)^{b}$ & 0.05 & $0.229(1.467)^{c}$ & $0.088(1.294)^{b}$ \\
\hline 200 & $0.048(1.21)^{\mathrm{d}}$ & $0.013(1.11)^{\mathrm{d}}$ & $0.08(1.28)^{c}$ & $0.042(1.20)^{c}$ & $0.129(1.349)^{\mathrm{d}}$ & $0.056(1.233)^{\mathrm{c}}$ \\
\hline 250 & $0.014(1.12)^{\mathrm{d}}$ & $0.006(1.08)^{\mathrm{e}}$ & $0.03(1.16)^{\mathrm{d}}$ & $0.023(1.14)^{d}$ & $0.042(1.201)^{\mathrm{e}}$ & $0.029(1.163)^{\mathrm{d}}$ \\
\hline
\end{tabular}

Means with the sameletter are not significantly different; data in parenthesis are square root transformed

\section{Seedling fresh and dry weight}

High seedling fresh and dry weight of 0.314 and $0.097 \mathrm{~g}$, respectively were obtained from local cultivar. Low seedling fresh weight was recorded by Huluka. Inducing progressive moderate water stress (100 and $150 \mathrm{~g} \mathrm{~L}^{-1}$ ) caused a significant decrease in seedling fresh weight whereas drastic decreases in seedling fresh and dry weights were observed at progressive severe stress (200 and $250 \mathrm{~g} \mathrm{~L}^{-1}$ ) level.

\section{Shoot and root growth inhibition}

Higher shoot length inhibition were observed for Danda'a cultivar followed by Huluka. On the other hand, Huluka's root growth was more inhibited than Danda'a. Moderately, more root and shoot growth (less inhibition) was recorded by Kubsa. Higher difference inhibition percentage between shoot and root was observed for Danda'a and Kubsa cultivar thus shoot growth was more inhibited than root growth. Huluka and local cultivar shoot and root were less affected by water stress (Fig. 1). Wheat shoot growth was more inhibited than root length under PEG induced water stress. Shoot growth inhibition was more at $150 \mathrm{~g} \mathrm{~L}^{-1}$ PEG than shoot at $200 \mathrm{~g} \mathrm{~L}^{-1}$ at PEG. At maximum water stress, the inhibition power of PEG for shoot was slightly higher than root length indicating that PEG induced water stress had inhibited root elongation at lesser rate than shoot growth. Similar results were also reported in pearl millet and chickpea by Kalefetogllu et al. (2009) and Govindaraj et al. (2010), respectively. Shoot and root growth inhibition increased with increase in water stress levels (Fig. 2).

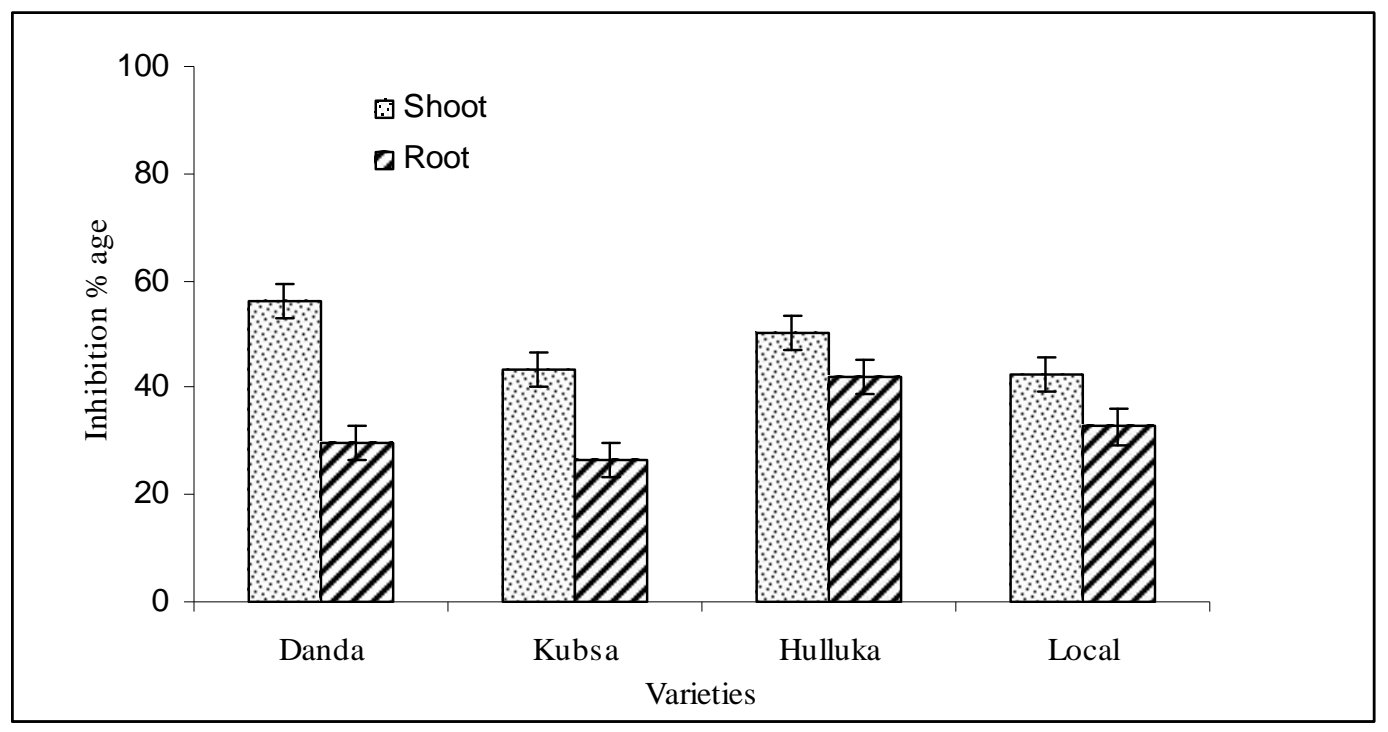

Fig. 1. Shoot and root length inhibition response of wheat cultivars under water stress 


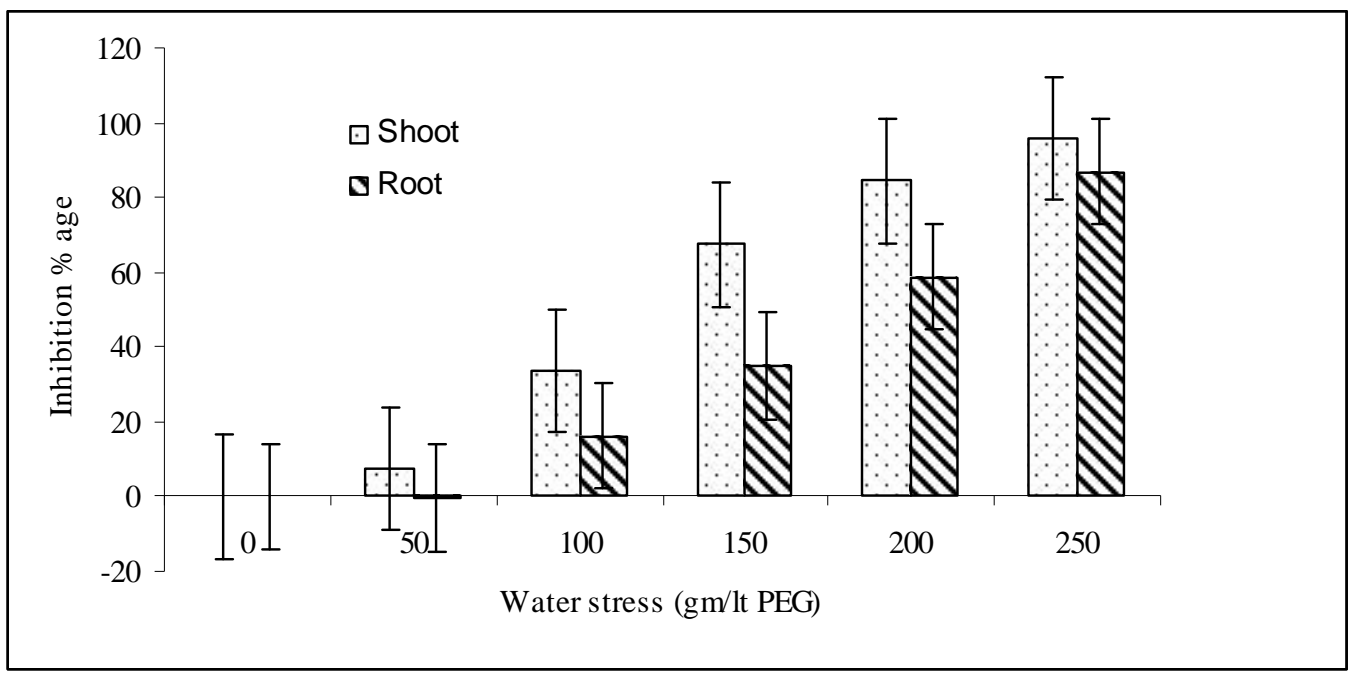

Fig. 2. Inhibition effects of different PEG concentration on wheat shoot and root length

\section{Conclusion}

All the wheat cultivars showed significant difference in germination percentage and rate. The local variety was superior over the released varieties in producing highest germination percentage and rapid rate of germination. In addition, the seedling vigor index of the local variety was superior to the rest cultivars. The germination indexes of wheat cultivars showed a diminishing trend with progressive increase in PEG concentration. The result showed that there was no significant difference among the wheat cultivars in producing taller shoot and root length. Increasing water stress levels has significantly reduced both root and shoot lengths. PEG induced water stress inhibited shoot growth more than root growth. The local cultivar was also able to produce more root numbers, shoot fresh and dry weight, seedling fresh and dry weight. The progressive moisture stress significantly reduced the wheat seedling growth parameters. Therefore, the current research suggests that the local cultivar is more tolerant to moisture stress and it could be used for breading tolerant cultivars. In addition, both germination indices and seedling growth parameters could be used for screening wheat cultivars for drought tolerance.

\section{References}

Almansouri, M., Kinet, J.M. and Lutts, S. 2001. Effect of salt and osmotic stresses on germination in durum wheat (Triticum durum Desf.). Plant Soil, 231: 243-254.

Bayoumi, T.Y., Manal, H. and Metwali, E.M. 2008. Application of physiological and biochemical indices as a screening technique for drought tolerance in wheat genotypes. African J. Biotech. 7 (14): 2341-2352.
Bibi, A., Sadaqat, H.A., Akram, H. M. and Mohammed, M.I. 2010. Physiological markers for screening sorghum (Sorghum bicolor) germplasm under water stress condition. Int. J. Agric. Biol. 12: 451- 455.

Boureima, S., Eyletters, M., Diouf, M., Dio, T.A. and Damme, P.V. 2011. Sensitivity of seed germination and seedling radicle growth to drought stress in sesame (Sesamum indicum L). Res. J. Envi. Sci. 5 (6): 557-564.

Cokkizgin, A. 2013 Effects of hydro and osmopriming on seed vigor of pea (Pisum sativum L). Agric. Forestry \& Fish. 2 (6): 225-228.

CSA, 2011. Statistical abstract of 2009/10. Central Statistical Agency, Addis Ababa, Ethiopia. p. 106.

Dhanda, S.S., Sethi, G.S. and Behl, R.K. 2004. Indices of drought tolerance in wheat genotypes at early stages of plant growth. J . Agron. Crop. Sci. 190: 6-12.

Gharoobi, B., Ghorbani, M. and Ghasemi Nezhad, M. 2012. Effects of different levels of osmotic potential on germination percentage and germination rate of barley, corn and canola. Iranian J. Plant Physiol. 2 (2): 413-417.

Govindaraj, M., Shanmugasundaram, P., Sumathi, P. and Muthiah, A.R. 2010. Simple, rapid and cost effective screening method for drought resistant breeding in pearl millet. Electronic J. Plant Breed. 1(4): 590- 599.

Guo, R., Hao, W. and Gong, D.Z. 2012. Effects of water stress on germination and growth of linseed seedlings (Linum usitatissimum), photosynthetic efficiency and accumulation of metabolites. J. Agril. Sci. 4 (10): 253-265.

Hosseein, A.F. and Kasra, M. 2011. Effect of hydropriming on seedling vigour in basil (Ocimum basilicum L.) under salinity conditions. Adv. Env. Biol. 5(5): 828-833.

ISTA. 1999. International Rules for Seed Testing. Seed Science and Technology, 27, 
International Seed Testing Association. p. 324.

Kalefetogllu, M.T., Turan, O. and Ekmekci, Y. 2009. Effect of water deficit induced by PEG and $\mathrm{NaCl}$ on Chickpea (Cicer arieitinum L.) cultivar and lines at early seedling stage. G.U. Sci. 22: 5-14.

Khodarahmpour, Z. 2011. Effect of drought stress induced by polyethylene glycol (PEG) on germination indices in corn (Zea mays L.) hybrids. African J. Biotech. 10 (79): 1822218227

Meneses, C.H.S.G., Alcantara Bruno, R.D. Fernandes, D., Pereira, W.E. Morais Lima, L.H.G., Andrade Lima, M.M. and Vidal, M.S. 2011. Germination of cotton cultivar seeds under water stress induced by polyethyleneglycol-6000. Sci. Agric. (Piracicaba, Braz.) 68 (2): 131-138.

Metwali, M.R., Manal, H.E. and Tarek, Y.B. 2011. Agronomical traits and biochemical genetic markers associated with salt tolerance in wheat cultivars (Triticum aestivum L). Australian J. Basic Appl. Sci. 5(5): 174-183.

Moraes, G.A.F., Menezes, N.L. and Pasqualli, L.L. 2005. Bean seed performance under different osmotic potentials. Ciencia Rural, 35: 776-780.

Pan, X.Y., Wang, Y.F., Wang, G.X., Cao, Q.D. and Wang, J. 2002. Relationship between growth redundancy and size inequality in spring wheat population mulched with clear plastic film. Acta Phytoecol Sinica, 26: 177-184.

Rauf, S., Sadaqat, H.A. and Khan, I.A. 2008. Effect of moisture regimes on combining ability variations of seedling traits in sunflower (Helianthus annuus L.). Candian J. Plant Sci. 88: 323-329.

Soltani, A., Gholipoor, M. and Zeinali, E. 2006. Seed reserve utilization and seedling growth of wheat as affected by drought and salinity. Environ. Exp. Bot. 55: 195-200.

$\mathrm{Xu}$, S.G., Wang, J.H. and Bao, L.J. 2006. Effect of water stress on seed germination and seedling growth of wheat. J. Anhui Agri. Sci. 34: 5784-5787.

Younis, M.E., El-Shahaby, O.A., Abo-Hamed, S.A. and Ibrahim, A.H. 2000. Effects of water stress on growth, pigments and assimilation in three sorghum cultivars. J. Agron. Crop Sci. 185: 73- 82. 